2014

\title{
The Freedom to Marry: Politics and Law in 2014 and Beyond
}

Ari Ezra Waldman

New York Law School

Follow this and additional works at: https://digitalcommons.nyls.edu/fac_other_pubs

Cart of the Family Law Commons, Law and Gender Commons, Sexuality and the Law Commons, and the Supreme Court of the United States Commons

\section{Recommended Citation}

Human Rights, Vol. 40, Issue 2 (July 2014), pp. 19-22

This Article is brought to you for free and open access by the Faculty Scholarship at DigitalCommons@NYLS. It has been accepted for inclusion in Other Publications by an authorized administrator of DigitalCommons@NYLS. 


\section{HEINONLINE}

Citation:

Ari Ezra Waldman, The Freedom to Marry: Politics and

Law in 2014 and beyond, 40 Hum. Rts. 19 (2014)

Provided by:

New York Law School<br>The Mendik Library

Content downloaded/printed from $\underline{\text { HeinOnline }}$

Sat Jan 13 20:23:55 2018

-- Your use of this HeinOnline PDF indicates your acceptance of HeinOnline's Terms and Conditions of the license agreement available at http://heinonline.org/HOL/License

-- The search text of this PDF is generated from uncorrected OCR text.

-- To obtain permission to use this article beyond the scope of your HeinOnline license, please use:

\section{Copyright Information}

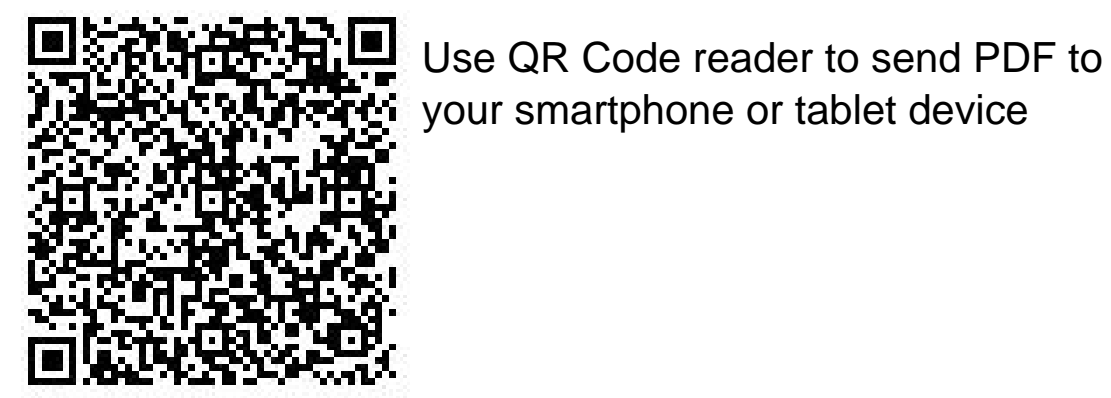




\section{The Freedom to Marry: Politics and Law in 2014 and Beyond}

By Ari Ezra Waldman

J une 26, 2013, was "marriage day" at the Supreme Court. On that day, the Court held the Defense of Marriage Act (DOMA) unconstitutional. This was one day after a different majority rejected the appeal in Hollingsworth v. Perry, the challenge to California's Prop 8 , ending that state's five-year aberration from marriage equality. A status update reporting the DOMA news on ScotusBlog's eponymous Facebook page got 1,119 "likes." The website's live blog had thousands of participants and, even before 9:00 a.m., was overflowing with questions in the queue. For a day, at least, the focus of the gay rights movement was squarely on the U.S. Supreme Court.

That singular focus was the result of several factors: DOMA, a federal law that denied federal recognition to lawful same-sex marriages in the states, required a federal solution, whether legislative repeal or judicial vacation. By 2012, the latter looked more likely. A repeal act failed to gain much traction in Congress while several lawsuits were successfully challenging DOMA's constitutionality in the federal courts. Mary Bonauto at the Gay and Lesbian Advocates and Defenders challenged DOMA on behalf of Nancy Gill in Massachusetts and won the first district court case to strike down the law. Lambda Legal's Tara Borelli won a sweeping victory in California on behalf of Karen Golinski. Roberta Kaplan, a partner at New York's Paul Weiss Rifkind Warton \& Garrison, LLP, and James Esseks, director of the ACLU LGBT Project, challenged DOMA on behalf of Edie Windsor. The Supreme
Court chose to hear their case alongside the challenge to California's Proposition 8. That we channeled extra special attention to the Court that day seems unsurprising.

Then came the decisions.

The Court punted in Perry, relying on lack of standing and refusing to address the underlying constitutional issue of the legality of sexual orientation-based marriage discrimination. But although only a narrow majority declared DOMA Section 3 unconstitutional, Justice Anthony Kennedy's decision in United States v. Windsor has inspired an avalanche of federal litigation from Utah to New Jersey and from Virginia to Texas to do what Perry was supposed to have done: overturn bans on marriage equality. Windsornot Perry - is blazing the path toward the freedom to marry in the states. Post-Windsor decisions in New Jersey, New Mexico, Ohio, Utah, Oklahoma, Texas, Michigan, Idaho, Arkansas, Oregon, and Pennsylvania suggest that the path may start outside of Washington, D.C., but may eventually lead back to the Supreme Court.

I would like to argue that the extraordinary strides forward in the marriage equality fight, in particular, and the gay rights movement, in general, are the products of a multipronged strategy of overwhelming force: in state courts and state capitals, in federal courts and in Washington. One unfortunate byproduct of that strategy is that it temporarily requires piecemeal progress on the road to victory, leaving lesbian, gay, bisexual, and transgender (LGBT) Americans in the awkward position of needing to know what state they're in before knowing if they are equal under the law. It also leaves equality open to continuous attack as we move from state to state. Therefore, a national litigation strategy, with Windsor at its core, will be essential to our ultimate victory.

\section{State Constitutional Litigation} A decade ago, many of the successful marriage equality lawsuits focused on state constitutions. Baehr v. Lewin (later recaptioned Baehr v. Miike) concluded that Hawaii's constitution required that marriage discrimination pass strict scrutiny. Baker v. Vermont held that denying marriage licenses to gays and lesbians violated Vermont's common benefits clause. And, of course, Goodridge v. Department of Health mandated marriage equality under Massachusetts's constitution. Later, Connecticut and Iowa would affirm equality through their own state courts and under their own constitutions. This generation of marriage cases had to be state based; some of them were filed before Lawrence v. Texas-namely, when Bowers v. Hardwick was still good law. Bowers not only gave conservatives license to discriminate against gays, but also made the federal courts hostile places for gay rights, in general. Plus, marriage equality in the federal courts was supposedly hampered by Baker v. Nelson, a 1971 Minnesota gay marriage case rejected by the Supreme Court for lack of a federal question. 
But the Court's decision in Windsor gave state-based marriage equality litigation a radically new look. Before Windsor, successful suits challenging marriage discrimination in Massachusetts, Connecticut, and Iowa included the same basic argument: Taking similarly situated individuals - those who want to marry the person they love - and treating them differently based on their sexual orientations violated equal protection guaranteed by state constitutions. Windsor helped state advocates make that argument under state law in two ways.

First, the case made it easier to challenge the separate-and-unequal institution of civil unions. Windsor said that legally married same-sex couples have to be granted access to the multitude of federal benefits that attend marriage; the case turned "skim milk marriages" into real ones. But those in civil unions or domestic partnerships are not, technically, "married." They fall outside of Windsor's orbit of fairness. As such, the inherent injustice of the separateand-unequal unions were put into stark relief and it allowed advocates, like those in New Jersey, to argue that the state constitution's guarantee of equality demanded including gays and lesbians in the institution of marriage. Civil unions, despite their extensive attendant state benefits, would never be equal to marriage, especially now that, after Windsor, same-sex marriages - and marriages alone - received all the same benefits as opposite-sex marriages. This argument could have applied to the other states that permitted gays and lesbians to enter into civil unions but denied them the honorific of marriage. But, as we have seen, the marriage fights in those statesOregon, Nevada, Colorado, and Wisconsin - are part of the flood of post-Windsor federal cases.

Second, the substance of Justice Kennedy's Windsor opinion gave all other state-based litigation a leg up. Consider New Mexico, which

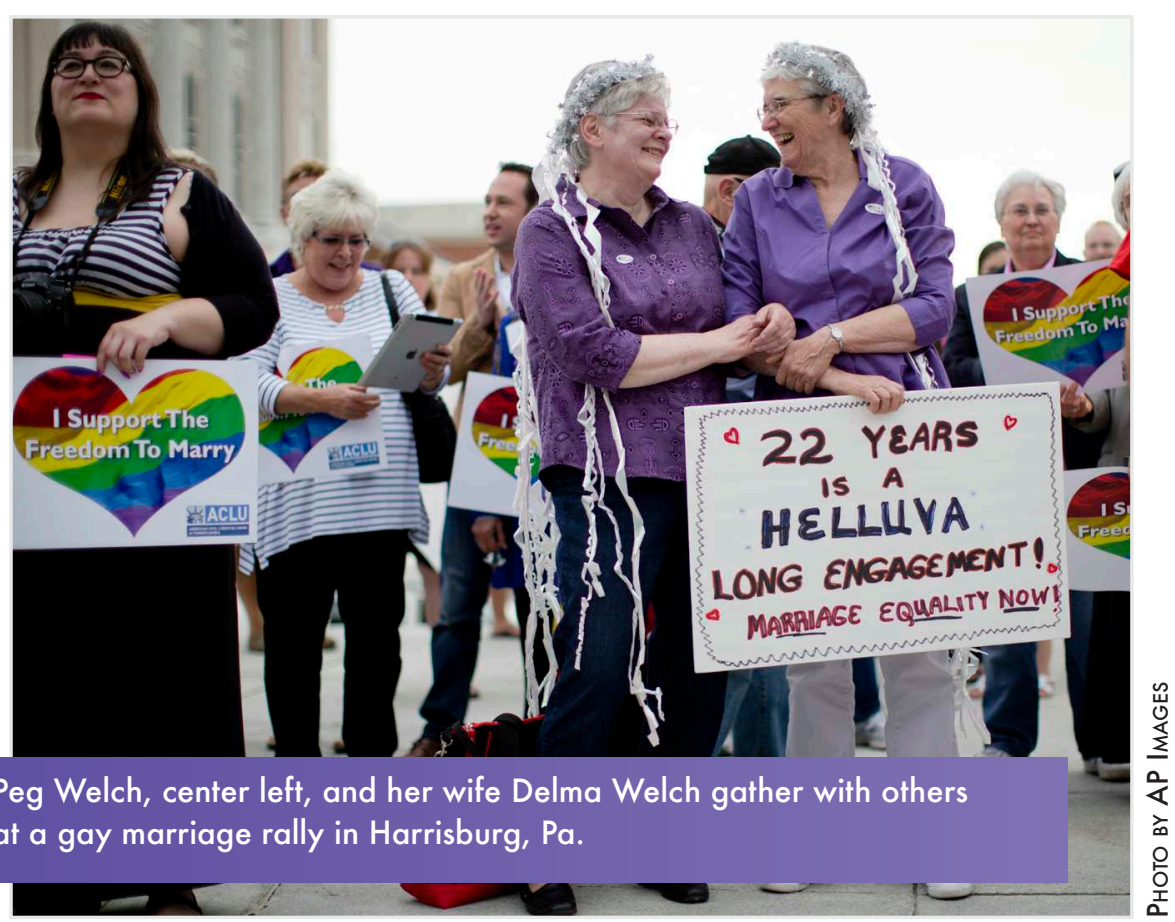

became the 17 th marriage equality state after a unanimous decision by its supreme court in December 2013. New Mexico never explicitly banned gays from marrying; rather, it had layered marriage laws that, taken together, made same-sex marriage impossible. The plaintiffs in New Mexico argued that they are just like opposite-sex couples: committed, in love, and desirous of the state recognition and benefits associated with marriage. They, therefore, should be treated equally. The state supreme court agreed and cited Windsor as evidence of that inherent equality under the law. Windsor may not have explicitly decided the issue of the constitutionality of state marriage discrimination, but it was a statement of LGBT equality and dignity and it eviscerated the remaining arguments that advocates of discrimination had been using. As such, it has become the strongest weapon in any LGBT advocate's arsenal.

\section{State Political Activism}

State-based litigation is only part of the story. The push for marriage equality is not a strictly legal quest; it is a broader social movement that requires public education, engagement on the ground, and changing hearts and minds. You cannot achieve those goals while remaining cloistered inside a courtroom, federal or state. And yet, pursuing a legislative strategy to achieve marriage equality at the state level raises the specter of political horse trading and hollow victories.

Many of our victories have been in the legislative sphere, but at state capitals, not in Washington, D.C., Delaware, Hawaii, Illinois, Minnesota, New Hampshire, New York, Rhode Island, and Washington State ushered in eras of marriage equality through legislative vote. Two of those were affirmed by statewide plebiscites, which is how Maine joined the club.

Take, for example, what happened in Illinois. That state's governor signed a marriage equality bill in November 2013, but it had not yet taken effect when, on February 21, 2014, a federal judge declared the state's ban on gays marrying unconstitutional. So the freedom to marry in Illinois is the product of combined legislative and 
litigation strategies. A coalition of LGBT groups, led by James Bennett of Lambda Legal, brought Illinois from marriage discrimination to civil unions to marriage. Lambda, which had been planning a marriage lawsuit when the civil unions debate was raging, selected a diverse group of plaintiffs that represented the disparate socioeconomic, racial, and geographic elements of the state. This allowed the plaintiffs to become the chief spokespersons and advocates when the legislature took up a marriage equality bill. They met with lawmakers of both parties in small, closed-door meetings, but also told their story to a wider audience, starring in commercial advertisements. They took a page from the movement's post2008 playbook and spoke about love, commitment, responsibility, and togetherness, rather than esoteric concepts of rights and equal treatment. Advocates also used the marriage lawsuit as a stick in the carrot-and-stick negotiations over a legislative response. And they won.

To win the legislative victory, though, they had to hold the line on the proposed religious exemptions to the law. This brings us to the real danger of a state-based legislative approach. Religious exemptions to marriage equality legislation permit religious institutions, however defined, to continue to discriminate against gay couples if such behavior is in line with their particular interpretation of their religious scripture. Some of these exemptions are eminently reasonable: A Catholic Church should not be forced by the state to perform and recognize a same-sex marriage if its doctrine opposes it. No one wants that. Others are miles north of dangerous: Certain proposed "conscience clauses" would allow a county clerk in a marriage equality state to refuse to issue a marriage license to a same-sex couple if the idea of same-sex marriage offends him or her personally.
These religious exemptions are doughnut holes that allow homophobes to deny rights to gays and lesbians for pretextual and offensive reasons, reasons that reject basic and long-settled principles of fairness, equality, and the common good. And we cannot accept them just to get a gay rights bill passed. Already, marriage equality advocates encouraged allies in the New Jersey legislature to table a bill that would have enshrined that state's courtmandated freedom to marry because the religious exemption was too broad. Many advocates also balked at the large religious exemption in the Employment Non-Discrimination Act that passed the Senate last year. If we let these exemptions grow, our victories could be a mile wide, but barely an inch deep.

This is not to suggest that stateby-state political activism should shut down because of the risk, especially once we reach the Deep South. The symbiotic relationship between state-based activism and a litigation strategy is evidence from states like Illinois, Oregon, and Colorado, all of which had boots on the ground that helped soften the political landscape when the federal judges handed down their marriage equality orders. Indeed, political mobilization is essential if we want to create a growing, stable, and permanent majority of LGBT allies. And there is movement on marriage freedom even in the most conservative of states: A recent poll out of South Carolina suggests that opposition to marriage freedom dropped 17 points in two years, with a corresponding rise in support. The 2013 version of this snippet of the Dixie electorate is still nowhere near majority support for LGBT equality (only 39 percent are in support), but the poll, if accurate, evidences a major shift in a deeply conservative state.

But, as it stands, this country is divided in two. Two loving and committed couples can be separated by a road, a river, or an invisible line of latitude and have widely different rights under the law. As of this writing, the freedom to marry covers nearly 45 percent of the American population (19 states and the District of Columbia, but not including states where the orders striking down the bans have been stayed). The line separating the equal from the unequal means the difference between having joint parental rights over an adopted child or, at law, having one parent be no closer to that child than a babysitter. It means the difference between sitting by your ailing partner in a hospital and being forced apart at the most crucial of moments because hospital rooms are for families only. And it means the difference between having the right to bury your loved one and being banned from his funeral.

\section{Federal Litigation and the Impact of United States v. Windsor}

The flurry of federal marriage litigation will erase these devastating divisions. And Windsor is the heart of that strategy. In Ohio, a federal judge issued a narrow decision declaring that state's constitutional amendment banning same-sex marriage was unconstitutional as it applied to death certificates. Windsor was a deciding factor in that decision. Again citing Windsor, a federal court in Utah brought marriage equality to that most conservative of states and let several thousand couples marry before a stay from the Supreme Court stopped them. In January and February 2014, federal judges in Oklahoma and Virginia, respectively, declared those states' bans on same-sex marriage unconstitutional. Both decisions are stayed; both decisions relied on Windsor. In Michigan, where a bench trial was delayed pending the Supreme Court's decisions in Perry and Windsor, a district court judge threw out a ban on same-sex marriage with conclusions of law indebted almost entirely to Windsor. In Arkansas, 
Circuit Judge Christopher Piazza cited or mentioned Windsor 13 times in a 13-page order. Idaho's Chief Magistrate Judge Candy Wagahoff Dale used Windsor 45 times. Windsor was cited 25 times by Oregon District Judge Michael McShane and nearly as many times by Judge John Jones of Pennsylvania.

The numbers are indeed dramatic - not to mention the 70 pending lawsuits covering all but one state (as of this writing) and all of them relying on Windsor, the 1,509 citing references to the case, and the 12-case post-Windsor marriage equality winning streak. But the numbers paint only part of the picture. Windsor's most remarkable and lasting contribution is its substance. While scholars parse Justice Kennedy's Windsor decision and discuss its significance, its innovations, and its missing pieces, the lower federal courts are giving us answers: Windsor is having an impact far beyond the narrow confines of DOMA and those already legally married same-sex couples who sought access the myriad federal benefits that attend marriage. To judges in Virginia, Oklahoma, Utah, Arkansas, Idaho, Oregon, and Pennsylvania, Windsor was a clear statement of equality: If the federal government has to treat all marriages, gay or straight, the same, there could be no legitimate rationale for treating the individuals in those marriages, gay or straight, any differently. To the Ninth Circuit, Windsor went even further. In patent law-cumgay rights case involving the cost of HIV medications, the Ninth Circuit went so far as to hold that Windsor now requires heightened scrutiny for state actions that discriminate on the basis of sexual orientation. Windsor has been cited for the principle that all gay persons are entitled to equal dignity, that any ostensible state interest in encouraging opposite-sex couples to marry is unrelated to banning gays from the institution, that the erroneous view that one-man-onewoman households are "optimal" for child rearing cannot justify antigay marriage discrimination, that preventing gays from marrying actually harms children and does violence to family cohesion, that the extraordinary step of denying marriage rights and benefits may be evidence of the antigay animus of its proponents, and that marriage discrimination does irreparable harm to the stabilizing force of the family, to name just a few of Windsor's substantive contributions. Indeed, Windsor was so strong a statement on the invalidity of gay marriage bans that Nevada, faced with the prospect of defending its ban in a post-Windsor world, decided to give up rather than tilt at windmills.

Increasingly, these federal cases will be the only way to continue the marriage equality winning streak. Political realities in countless conservative states mean that after so many victories in 2012 and 2013, the list of viable pro-equality legislatures is wearing frighteningly thin. But honest judges of all political stripes are in abundance. The equality and due process principles at the heart of the freedom to marry for gay couples are so evident, so clear, and so part of our constitutional tradition that liberal and conservative judges alike are lining up to outdo each other as they toss antigay marriage bans onto the ash heap of history. Some judges, like the openly gay Judge McShane, added personal touches to their orders. Judge McShane recalled the indecencies, big and small, of the homophobia and hate he experienced both as a young man and as an adult and hoped that his and his colleagues' decisions on marriage equality would nudge the scales even further toward tolerance and acceptance. Judge McShane's political opposite, Judge Jones of Pennsylvania, may have been a Republican appointee and an avowed conservative, but his decision was actually more sweeping.

And the domino-like effect of these decisions impacts hearts and minds of the American public, as well. The latest national polling data shows that 57 percent of the American public supports the freedom to marry. Conservative politicians are ceding that marriage equality is an obvious eventuality, and young Republicans are vastly pro-equality. Our many legal victories, all of which are indebted to Windsor, validate and legitimize marriage for all couples, gay or straight. Windsor, therefore, has done something remarkable: It has made opposition to marriage equality nothing short of irrational.

Winning a national right to marry, then, is taking us through the federal courts. There is even a chance we may not need the Supreme Court to step in. Our post-Windsor winning streak shows no sign of abating and we had favorable hearings at the Tenth and Fourth Circuits in April and May 2014. Other marriage cases are winding their way through the remaining circuits except the First and the Second, two jurisdictions with full marriage equality already. Within a year, each remaining circuit court could issue a decision affirming the unconstitutionality of marriage discrimination, leaving no circuit split for the Supreme Court to resolve. Our step-by-step progress will be piecemeal and halting for a time, but it will still be progresssmall comfort to those who live beyond the boundaries of equalityas we inch closer to a conclusion, like a liberating army chipping away as it closes in on the capital. Our movement is racing through the federal courts, toppling barriers in the states along the way. This has made 2014 and beyond the years of the falling dominoes.

Ari Ezra Waldman is associate professor of law at New York Law School, the Paul F. Lazarsfeld Fellow and Ph.D. candidate in sociology at Columbia University, and the legal editor at Towleroad, award-winning LGBT news and politics blog. He can be reached at ari.waldman@nyls.edu and you can follow him on Twitter at (@)ariezrawaldman. 